\title{
EVALUATION OF LASER-GLAZED PLASMA-SPRAYED THERMAL BARRIER COATINGS UNDER HIGH TEMPERATURE EXPOSURE TO MOLTEN SALTS
}

\author{
C. Batista ${ }^{\mathrm{a}, *}$, A. Portinha $^{\mathrm{a}}$, R. M. Ribeiro ${ }^{\mathrm{a}}$, V. Teixeira ${ }^{\mathrm{a}}$ and C.R. Oliveira ${ }^{\mathrm{b}, \mathrm{c}}$ \\ ${ }^{a}$ University of Minho, Physics Department, Campus de Gualtar, 4710-057 Braga, Portugal, \\ ${ }^{\mathrm{b}}$ IDIT - Instituto de Desenvolvimento e Inovação Tecnológica, 4520-102 Santa Maria da Feira, Portugal \\ ${ }^{c}$ University Lusíada, 4760-108 Vila Nova de Famalicão, Portugal
}

Keywords: Hot corrosion; Laser glazing; Plasma spraying; Thermal barrier coatings; Zirconia; YSZ

\begin{abstract}
Thermal Barrier Coating (TBC) systems are frequently used in gas turbine engines to provide thermal insulation to the hot-section metallic components and also to protect them from oxidation, hot corrosion and erosion. Surface sealing treatments, namely laser-glazing, have been showing a high potential for extending in-service lifetimes of these systems by improving chemical and thermo-mechanical resistance. In this investigation, both as-sprayed and laserglazed TBCs were exposed to hot corrosion in molten salts. The glazed coatings were obtained by scanning the surface of the plasma-sprayed coatings with either a $\mathrm{CO}_{2}$ or a $\mathrm{Nd}$ :YAG laser. The hot corrosion investigation was accomplished by subjecting the specimens to an isothermal air furnace testing under $\mathrm{V}_{2} \mathrm{O}_{5}$ and/or $\mathrm{Na}_{2} \mathrm{SO}_{4}$ in a temperature of $1000^{\circ} \mathrm{C}$ for 100 hours. Spallation has been observed in coatings in the as-sprayed condition under $\mathrm{V}_{2} \mathrm{O}_{5}$ or
\end{abstract}

* Corresponding author. Tel.: +351-253 604 335; Fax: +351-253 678981.

Address: University of Minho, Physics Department, Campus de Gualtar, 4710-057 Braga, Portugal.

E-mail address: cbatista@ fisica.uminho.pt (C. Batista). 
$\mathrm{V}_{2} \mathrm{O}_{5}+\mathrm{Na}_{2} \mathrm{SO}_{4} \cdot \mathrm{Na}_{2} \mathrm{SO}_{4}$ itself had no or minimal effect on the degradation of the laser-glazed or as-sprayed condition coatings, respectively. The degradation in $\mathrm{V}_{2} \mathrm{O}_{5}$ was accomplished by destabilization of YSZ as a consequence of depletion of yttria from the solid solution to form $\mathrm{YVO}_{4}$ and therefore led to the disruptive transformation of the metastable tetragonal phase to the monoclinic phase. Moreover, the presence of both corrosive salts induced the formation of large high aspect ratio $\mathrm{YVO}_{4}$ crystals that introduced additional stresses and contributed to the degradation of the coatings. The laser-glazed specimens were not efficient in avoiding the molten salt penetration along the thickness direction due to the presence of cracks on the glazed layer. However due to a reduced specific surface area of the dense glazed layer, the corrosion reaction of the molten salts with the YSZ has been lower than in coatings in the as-sprayed condition. 


\section{Introduction}

Ceramic Thermal Barrier Coating (TBC) systems are frequently used in gas turbine engines to provide thermal insulation to the hot-section metallic components (vanes, blades, shrouds, etc.) and also to protect them from oxidation, hot corrosion and erosion, extending the components thermo-mechanical life [1,2].

Zirconia stabilized with $8 \mathrm{wt} \%$ of yttria (8YSZ), the most commonly used material as a TBC, has been developed over many years and is thought to give the best performance, especially in aviation gas turbines [3]. Yttria stabilizes zirconia in the tetragonal phase preventing it from undergoing a transformation to a monoclinic phase that is accompanied by an increase in volume (up to 5\%) that produces stresses and eventually causes delamination and spalling of the coating [3-5].

TBCs have limited applications in industrial gas turbines and diesel engines because the commonly used stabilizers of zirconia react with sulfur, sodium and vanadium contaminants contained in many industrial low-quality fuels $[3,6,7]$. Furthermore, particularly in plasmasprayed coatings, the penetration of these contaminants through the porous and microcracked coating may also attack the underlying metallic components by hot corrosion mechanisms.

Hot corrosion can be defined as accelerated corrosion that results from the presence of salt contaminants such as $\mathrm{Na}_{2} \mathrm{SO}_{4}, \mathrm{NaCl}$ and $\mathrm{V}_{2} \mathrm{O}_{5}$ which form molten deposits that react with the protective oxide coatings [7,8]. Laser-glazing has been mentioned by Jones [3] and Gurrappa [6], as an approach to improve the hot corrosion resistance of zirconia-based thermal barrier coatings by preventing salt penetration into the coating.

Laser-glazing provides a remelting and subsequent solidification of the surface resulting on a dense top layer with a new microstructure with reduced surface roughness, free from porosity but 
with formation of crack networks perpendicular to the surface [10-13,16-27]. Moreover, this post-treatment technique is suitable for surface treatment without structural modification of the zirconia nontransformable tetragonal phase because of the rapid solidification and subsequent cooling $[10,11,16]$.

Studies conducted by Tsai and Hsu [13] reported that laser-glazing provided an increase of about fourfold in the lifetimes of the plasma-sprayed $\mathrm{ZrO}_{2}-19.5 \mathrm{wt} \% \mathrm{Y}_{2} \mathrm{O}_{3}$ TBCs in a $\mathrm{V}_{2} \mathrm{O}_{5}$ saltcontaining corrosive environment resulting from the improvement of strain accommodation through segmented cracks and from the reduction of penetration of the molten salts through the dense glazed layer.

In this paper, a study with focus on the hot corrosion response of laser glazed 8YSZ coatings relatively to those in the as-sprayed condition is reported. The mechanisms of destabilization of the coatings are studied and the effect of $\mathrm{V}_{2} \mathrm{O}_{5}$ and $\mathrm{Na}_{2} \mathrm{SO}_{4}$ is examined separately as well as in conjunction due to possible mixed interactions that may inhibit or enhance the hot corrosion effect. 


\section{Experimental details}

\subsection{Material}

The specimens used in this study consisted of a conventional TBC system comprising an atmospheric plasma-sprayed (APS) 8YSZ (Metco 2004 NS) top coat deposited onto stainless steel disks (ASTM 316Ti) pre-coated with a vacuum plasma-sprayed (VPS) bond coat (PWA 286). The substrate disks $(\varnothing 3 \times 0.3 \mathrm{~cm})$ had been previously grit blasted with alumina particles for roughening of the surface assuring an improved adhesion of the coatings. Table 1 shows the main spraying process parameters and coating characteristics. The specimens were then cut in four parts with an average area of about $1.77 \mathrm{~cm}^{2}$ to proceed with the glazing process and hot corrosion testing.

\subsection{Laser glazing}

The laser glazing process was carried out using a $\mathrm{CO}_{2}$ (Trumpf Lasercell 1005, TLF series) and a Nd:YAG (StarMark SME65, Baasel Lasertech GmbH,) pulsed industrial lasers. The specimens were placed on the $x-y$ table and in both cases the laser beam was scanned over the specimen surfaces generating multiple parallel tracks of controlled overlapping to treat the whole surface area of the coatings. Some of the laser operating parameters are listed in Table 2.

\subsection{Corrosion testing}


Both laser-glazed and as-sprayed specimens were used in the hot corrosion test. The chosen corrosive compounds were vanadium pentoxide $\left(\mathrm{V}_{2} \mathrm{O}_{5}\right)$ and sodium sulfate $\left(\mathrm{Na}_{2} \mathrm{SO}_{4}\right)$ high-purity powder salts. In order to study the effect of $\mathrm{V}_{2} \mathrm{O}_{5}$ and $\mathrm{Na}_{2} \mathrm{SO}_{4}$ separately and combined three series of specimens were prepared for this study:

1) Specimens with $\mathrm{V}_{2} \mathrm{O}_{5}$ in a concentration of $15 \mathrm{mg} / \mathrm{cm}^{2}$;

2) Specimens with $\mathrm{Na}_{2} \mathrm{SO}_{4}$ in a concentration of $25 \mathrm{mg} / \mathrm{cm}^{2}$;

3) Specimens with a mixture of $60 \mathrm{wt} \% \mathrm{~V}_{2} \mathrm{O}_{5}-40 \mathrm{wt} \% \mathrm{Na}_{2} \mathrm{SO}_{4}$ in a concentration of $25 \mathrm{mg} / \mathrm{cm}^{2}$.

The corrosive powders were placed and spread over the surface of the coatings leaving approximately $3 \mathrm{~mm}$ from the edge uncovered. All specimens were subjected to an isothermal air furnace testing at a temperature of $1000^{\circ} \mathrm{C}$ for 100 hours followed by cooling down to room temperature inside the furnace. For ease of specimen referencing abbreviations are used in the paper which are presented in Table 3.

\subsection{Characterization}

Coating surfaces, fracture planes and cross-sections were prepared and examined by scanning electron microscopy (SEM) in order to determine morphological and microstructural modifications. Energy dispersive X-ray spectroscopy (EDS) was used as a complement of X-ray diffraction (XRD) for local element analysis and detection of corrosion products along throughthickness. Phase stability of zirconia was studied by means of XRD using a X-ray diffractometer operating with a continuous scan of $\mathrm{Cu} \mathrm{K}_{\alpha 1}$ radiation with $1.54056 \AA$ wavelength and a step size of $0.02^{\circ}$. 


\section{Results and discussion}

\subsection{Coating morphologies before the hot corrosion testing}

Fig. 1 depicts the initial surface morphology of the TBCs used in the hot corrosion test. Both laser-glazed coatings presented a considerable reduction of the surface roughness if compared with the as-sprayed ones. In addition, the surface porosity was eliminated but a network of cracks perpendicular to the surface has formed in both cases. The crack density is similar in both, however the width of the cracks is substantially smaller in those treated with Nd:YAG laser. Also, voids were found at the surface of the $\mathrm{CO}_{2}$ laser-glazed coatings while none has been noticed in those treated with the Nd:YAG laser. The microstructure of the glazed layers changed from lamellar to columnar due to the direction of the heat flow on cooling down to room temperature.

\subsection{Hot corrosion response}

\subsubsection{Visual inspection}

After the hot corrosion test, the coating Sprayed $-\mathrm{V}_{2} \mathrm{O}_{5}$ was integral but fully detached from the substrate. The coating Sprayed-MIX was severely damaged presenting large portions of spalled material. The laser glazed coatings initially covered either with $\mathrm{V}_{2} \mathrm{O}_{5}$ or $\mathrm{V}_{2} \mathrm{O}_{5}+\mathrm{Na}_{2} \mathrm{SO}_{4}$ were integral but perceptibly weakened. The specimens covered solely with $\mathrm{Na}_{2} \mathrm{SO}_{4}$ did not show signs of degradation. Regardless the condition of the coatings, all substrates presented their external surfaces considerably damaged by high temperature oxidation. 


\subsubsection{Microscopic surface examination}

SEM observations of the various surfaces after the corrosion testing are depicted in Fig. 2 and reveal evident morphological modifications and particular features in some of the coatings.

Specimens tested with $\mathrm{Na}_{2} \mathrm{SO}_{4}$ (Fig. 2a,b,c) did not show visible signs of degradation of the initial surface morphology although a slight increase of porosity has been noticed for the assprayed condition specimen (Fig. 2a). Moreover, no Na- or S-containing products have been found at the surface by EDS probably due its low content below the detection limit of the XRD diffractometer.

Specimens tested with $\mathrm{V}_{2} \mathrm{O}_{5}$ (Fig. 2d,e,f) or $\mathrm{V}_{2} \mathrm{O}_{5}+\mathrm{Na}_{2} \mathrm{SO}_{4}$ (Fig. 2g,h,i) presented their surfaces highly porous and in particular those in the as-sprayed condition (Fig. 2d,g). The assprayed coating tested with $\mathrm{V}_{2} \mathrm{O}_{5}+\mathrm{Na}_{2} \mathrm{SO}_{4}$ was extremely damaged and showed significant amounts of detached material (Fig. 2d). In specimens corroded by $\mathrm{V}_{2} \mathrm{O}_{5}+\mathrm{Na}_{2} \mathrm{SO}_{4}$, lace-like agglomerates of crystals were found. The crystals presented a high aspect ratio with needles up to $100 \mu \mathrm{m}$ long. On the other hand, specimens corroded solely by $\mathrm{V}_{2} \mathrm{O}_{5}$ only showed irregular crystals embedded on the surface (Fig. 2d,e,f). It was found by EDS analysis (Fig. 3) that the crystals in both cases were composed of yttrium, vanadium and oxygen and confirmed to be $\mathrm{YVO}_{4}$ by XRD analysis.

\subsubsection{Structural analysis and phase destabilization}

Zirconia-based TBCs require alloying oxides such as $\mathrm{Y}_{2} \mathrm{O}_{3}, \mathrm{CaO}, \mathrm{CeO}, \mathrm{MgO}$, etc., in order to stabilize a single-phase material, usually in the tetragonal form [28]. At room temperature the 
equilibrium phases of yttria partially stabilized zirconia are expected to be a low yttria content monoclinic phase and a high yttria content cubic phase. However, due to rapid cooling during the plasma-spraying process, a nonequilibrium tetragonal phase, denoted as t', takes place $[29,30]$.

Fig. 4 shows the XRD spectra of the surface of all coatings before and after the corrosion testing. Before the corrosion testing (top patterns of Fig. 4a,b,c), XRD analyses revealed, for all three series of coatings a polycrystalline structure composed solely by the nontransformable t' tetragonal phase which indicates that both laser systems are suitable for surface treatment without structural modification of zirconia. Moreover, $\mathrm{ZrO}_{2}-8 \mathrm{wt} \% \mathrm{Y}_{2} \mathrm{O}_{3}$ plasma-sprayed coatings may contain small amounts of residual monoclinic phase that can be suppressed by laser-glazing $[10,11,31]$. It was also detected some minor relative peak intensity variation due to columnar grain orientation caused by the laser-glazing process.

$\mathrm{Na}_{2} \mathrm{SO}_{4}$ itself did not have significant consequences on destabilization of zirconia $\left(2^{\text {nd }}\right.$ pattern of Fig. 4a,b,c). Only the one in the as-sprayed condition presented some traces of monoclinic phase (less than $2 \%$, Fig. 5). The specimens corroded either by $\mathrm{V}_{2} \mathrm{O}_{5}+\mathrm{Na}_{2} \mathrm{SO}_{4}$ or $\mathrm{V}_{2} \mathrm{O}_{5}$ presented a high monoclinic/tetragonal peak intensity ratio indicating a destabilization of zirconia ranging from $87 \%$ to $97 \%$. Moreover, the intensity of the main peak of $\mathrm{YVO}_{4}$ is noticeably higher in specimens corroded by $\mathrm{V}_{2} \mathrm{O}_{5}+\mathrm{Na}_{2} \mathrm{SO}_{4}$ and is related with the formation of the large needle-like $\mathrm{YVO}_{4}$ crystals (Fig. 2g,h,i).

In order to determine the hot corrosion response of the tested coatings, the extent of destabilization was determined by calculating the volume fraction of monoclinic phase formed at the end of the tests:

$$
\% m=\frac{I_{m(\overline{1} 11)}+I_{m(111)}}{I_{m(\overline{1} 11)}+I_{m(111)}+I_{t(111)}}
$$


where I represents the diffraction intensity of the respective lattice planes.

A comparison of the destabilization fractions is presented in Fig. 5. It can be seen that $\mathrm{V}_{2} \mathrm{O}_{5}$ had a detrimental effect on the coatings leading to the transformation from tetragonal to monoclinic phase up to $97 \%$ in volume. The laser-glazed coatings reduced the destabilization at the surface although the effect was rather small (6-10\%). They presented less monoclinic phase than the plasma-sprayed ones, being in agreement with the results obtained by Tsai and Hsu [13]. The Nd:YAG laser-glazed coatings presented lower destabilization than those glazed with the $\mathrm{CO}_{2}$ laser as a result of a lower surface area due to absence of surface voids and smaller width of cracks (see Fig. 1b and c).

\subsubsection{Mechanisms of degradation}

Various studies [3,4,6,7,13-15] with focus on the hot corrosion of YSZ have reported the reaction of yttria, from the zirconia solid solution, with vanadium-containing compounds leading to the formation of yttrium vanadate $\left(\mathrm{YVO}_{4}\right)$ :

$\mathrm{ZrO}_{2}\left(\mathrm{Y}_{2} \mathrm{O}_{3}\right)+\mathrm{V}_{2} \mathrm{O}_{5} \rightarrow \mathrm{ZrO}_{2}($ monoclinic $)+2 \mathrm{YVO}_{4}$

The resultant structural destabilization of zirconia by depletion of yttria is followed by phase transformation from tetragonal to monoclinic.

Another possible chemical reaction would be the zirconia matrix itself with the molten vanadate: 
$\mathrm{ZrO}_{2}+\mathrm{V}_{2} \mathrm{O}_{5} \rightarrow \mathrm{ZrV}_{2} \mathrm{O}_{7}$

However, in this study no such products have been found by XRD analyses. This result is in conformity with literature that mentions the reaction kinetics is slow and not usually detected [3]. $\mathrm{V}_{2} \mathrm{O}_{5}$, a strongly acidic oxide, melted at approximately $690^{\circ} \mathrm{C}$, spread over the surface and easily infiltrated through open interlamellar porosity and cracks. The chemical degradation started at the contact surface between the molten salt and YSZ by nucleation and growth of $\mathrm{YVO}_{4}$ crystals (eq. 2). The $\mathrm{YVO}_{4}$ crystals formed in the presence of $\mathrm{V}_{2} \mathrm{O}_{5}$ solely were found to be very irregular in shape and strongly embedded on the surface.

A dissimilar morphology of the $\mathrm{YVO}_{4}$ crystals was found in the presence of $\mathrm{V}_{2} \mathrm{O}_{5}$ combined with $\mathrm{Na}_{2} \mathrm{SO}_{4}$. The crystals showed to be dissociated from the zirconia matrix and presented a needle-like shape up to $100 \mu \mathrm{m}$ long. In this case, during the exposure of the initial powder salt mixture of $\mathrm{V}_{2} \mathrm{O}_{5}-40 \% \mathrm{wtNa} \mathrm{SO}_{4}$ to high temperature, less acidic low melting sodium vanadates such as $\mathrm{NaVO}_{3}$ might have been given rise [3,32-34]:

$\mathrm{V}_{2} \mathrm{O}_{5}+\mathrm{Na}_{2} \mathrm{SO}_{4} \rightarrow 2\left(\mathrm{NaVO}_{3}\right)+\mathrm{SO}_{3}$

Then, $\mathrm{NaVO}_{3}$ having a melting point of $610^{\circ} \mathrm{C}$ [32] reacted with yttria from the zirconia solid solution to form $\mathrm{YVO}_{4}$ :

$\mathrm{ZrO}_{2}\left(\mathrm{Y}_{2} \mathrm{O}_{3}\right)+2\left(\mathrm{NaVO}_{3}\right) \rightarrow \mathrm{ZrO}_{2}($ monoclinic $)+2\left(\mathrm{YVO}_{4}\right)+\mathrm{Na}_{2} \mathrm{O}$ 
It seems that the molten $\mathrm{NaVO}_{3}$ has increased atom mobility enhancing the depletion of yttria and hence promoted the growth of $\mathrm{YVO}_{4}$ crystals. In terms of destabilization and consequent phase transformation the results are quite similar (Fig. 5).

In Fig. 6 is shown the surface appearance of the coating Sprayed-MIX where a portion of the coating has spalled. The destabilization and consequent phase transformation to monoclinic accompanied with volume increase has severely weakened the coating. Furthermore, the formation of the needle-like $\mathrm{YVO}_{4}$ crystals has introduced additional stresses to the damaged areas and hence contributed to the loss of material by spallation. On the other hand, the Sprayed$\mathrm{V}_{2} \mathrm{O}_{5}$ coating failed not by losses of material from the outermost surface but by detachment from the bond coat due to phase transformation induced-stresses near the top coat/bond coat interface.

Fig. 7 shows backscattered-electron micrographs illustrating cross-sectional views of coatings $\mathrm{CO}_{2}$-MIX and Sprayed-MIX. It can be seen in Fig. $7 \mathrm{~b}$ and $\mathrm{d}$ that in both cases pores and interlamellar gaps are filled with a compound chemically different from the zirconia matrix (slightly darker regions within the top coat) which was confirmed to be composed of yttrium, vanadium and oxygen by EDS analysis. The glazed layer has not been effective in avoiding molten salt infiltration due to the presence of surface cracks. The molten salts had deeply infiltrated through the whole thickness of the coatings reaching the top coat/thermally grown oxide (TGO) interface and reacted with yttria to form $\mathrm{YVO}_{4}$.

A fracture surface of coating $\mathrm{CO}_{2}$-MIX after the corrosion testing is shown in Fig. 8. It is clearly visible a preferential formation of $\mathrm{YVO}_{4}$ crystals just below the dense glazed layer where the contact area is much higher than that at the surface. The formation of those needle-like $\mathrm{YVO}_{4}$ crystals may contribute to the failure of the coating not only by promoting the disruptive phase transformation from tetragonal to monoclinic but also by introducing additional stresses and thus reduce the tolerance of the TBC to thermal shock. 
The laser-glazed or as-sprayed condition coatings exposed to $\mathrm{Na}_{2} \mathrm{SO}_{4}$ solely showed no or minimal signs of degradation, respectively. The degradation of $\mathrm{YSZ}$ by $\mathrm{Na}_{2} \mathrm{SO}_{4}$ may be given by [35]:

$\mathrm{ZrO}_{2}\left(\mathrm{Y}_{2} \mathrm{O}_{3}\right)+\mathrm{Na}_{2} \mathrm{SO}_{4} \rightarrow \mathrm{ZrO}_{2}$ (monoclinic) $+\mathrm{NaYO}_{2}$

$\mathrm{Na}_{2} \mathrm{SO}_{4}$ can react $\mathrm{Y}_{2} \mathrm{O}_{3}$ leading to the formation $\mathrm{NaYO}_{2}$ and, once again, due to destabilization of zirconia, transformation from tetragonal to monoclinic may be observed. In this study, although it has been observed small amount of monoclinic phase ( 2\%) in the plasma-sprayed coating, no reaction products of sodium and yttrium were found by XRD. Moreover, sodium and sulfur have not been detected by EDS either on the surface or along through thickness which suggests that those elements may have been vaporized during the exposure to high temperature.

The failure mechanisms observed in this study are in agreement with those proposed by Park et al [7] that refers three steps for the corrosion mechanism: a first in which the salt penetration into the entire thickness is observed; a second in which the penetrated salts react with the stabilizers of zirconia and; the final is completed by macroscale damage as a consequence of thermal and mechanical stresses that promote gradual losses of material from the surface (see Fig. 6). Furthermore, failure at or near the top coat/bond coat interface has also been observed in the specimen Sprayed- $\mathrm{V}_{2} \mathrm{O}_{5}$ which had fully spalled from the substrate. The molten $\mathrm{V}_{2} \mathrm{O}_{5}$ had deeply penetrated along the whole thickness of the coating, reacted with $\mathrm{Y}_{2} \mathrm{O}_{3}$ and the consequent phase transformation induced-stresses arisen at or near the top coat/ bond coat interface were released by detachment of the top coat. In the case of the laser-glazed specimens, since the molten salts may preferably attack the YSZ under the remelted dense layer (Fig. 8), the last failure step may be accomplished firstly by delamination of the external dense layer and then if 
continuously in service, behave as regular plasma-sprayed coating experiencing gradual losses of material from the surface and/or spallation near the top coat/bond coat interface. 


\section{Conclusions}

Laser-glazed and as-sprayed $\mathrm{ZrO}_{2}-8 \mathrm{wt} \% \mathrm{Y}_{2} \mathrm{O}_{3}$ plasma-sprayed thermal barrier coatings have been subjected to an isothermal air furnace testing under $\mathrm{V}_{2} \mathrm{O}_{5}$ and/or $\mathrm{Na}_{2} \mathrm{SO}_{4}$ corrosive media at a temperature of $1000^{\circ} \mathrm{C}$ for 100 hours.

Failure by spallation has been observed in coatings in the as-sprayed condition under $\mathrm{V}_{2} \mathrm{O}_{5}$ or $\mathrm{V}_{2} \mathrm{O}_{5}+\mathrm{Na}_{2} \mathrm{SO}_{4} . \mathrm{Na}_{2} \mathrm{SO}_{4}$ itself had no or minor effect on the degradation of the laser-glazed or assprayed condition coatings, respectively. The degradation in $\mathrm{V}_{2} \mathrm{O}_{5}$ was accomplished by destabilization of YSZ as a consequence of depletion of yttria from the solid solution to form $\mathrm{YVO}_{4}$ and consequently led to the disruptive transformation of the metastable tetragonal phase to the monoclinic phase. Moreover, the presence of both corrosive salts introduced additional stresses caused by formation of large aspect ratio $\mathrm{YVO}_{4}$ crystals that have contributed to further degrade the coatings.

The laser-glazed specimens were not efficient in avoiding the molten salt penetration along the thickness direction due to the presence of cracks on the glazed layer. However due to a reduced specific surface area of the dense glazed layer, the corrosion reaction of the molten salts with the YSZ has been lower than in coatings in the as-sprayed condition. A maximum decrease of approximately $10 \%$ in the destabilization of 8 YSZ has been achieved in the YAG laser-glazed specimen exposed to $\mathrm{V}_{2} \mathrm{O}_{5}+\mathrm{Na}_{2} \mathrm{SO}_{4}$. 


\section{Acknowledgments}

This work is part of the research project POCTI/CTM/44590/2002, approved by Portuguese Foundation for Science and Technology (FCT) and POCTI and supported by the European Community Fund FEDER.

The authors would like to thank Prof. Stöver, Dr. Vaßen and Dr. Buchkremer from the Institute for Materials and Processes in Energy Systems (IWV) in the Research Centre Jülich, Germany, for providing the necessary samples for this study.

A. Portinha is grateful for the research grants supported by the Portuguese Foundation for Science and Technology (FCT). 


\section{References}

[1] V. Teixeira, M. Andritschky, W. Fischer, H.P. Buchkremer, D. Stöver, Surf. Coat. Technol. 120-121 (1999) 103.

[2] A. Portinha, V. Teixeira, J. Carneiro, J. Martins, M.F. Costa, R. Vassen, D. Stoever, Surf. Coat. Technol. 195 (2005) 245.

[3] R.L. Jones, J. Therm. Spray Technol. 6(1) (1997) 77.

[4] S. Raghavan, M.J. Mayo, Surf. Coat. Technol. 160 (2002) 187.

[5] M.P. Borom, C.A. Johnson, L.A. Peluso, Surf. Coat. Technol. 86-87 (1996) 116.

[6] I. Gurrappa, J. Mater. Sci. Lett. 17 (1998) 1267.

[7] S.Y. Park, J.H. Kim, M.C. Kim, H.S. Song, C.G. Park, Surf. Coat. Technol. 190 (2005) 357.

[8] N. Eliaz, G. Shemesh, R.M. Latanision, Eng. Fail. Anal. 9 (2002) 31.

[9] M.R. Khajavi, M.H. Shariat, Eng. Fail. Anal. 11 (2004) 589.

[10] C. Batista, A. Portinha, R. Ribeiro, V. Teixeira, M.F. Costa, C.R. Oliveira, Surf. Coat. Technol. (2004), in press.

[11] C. Batista, A. Portinha, R. Ribeiro, V. Teixeira, M.F. Costa, C.R. Oliveira, Appl. Surf. Sci 247 (2005) 313.

[12] H.L. Tsai, P.C. Tsai, Surf. Coat. Technol. 71 (1995) 53.

[13] P.C. Tsai, C.S. Hsu, Surf. Coat. Technol. 183 (2004) 29.

[14] Z. Chen, N.Q. Wu, J. Singh, S.X. Mao, Thin Solid Films 443 (2003) 46.

[15] B.R. Marple, J. Voyer, C. Moreau, D.R. Nagy, Mater. High Temper. 17(3) (2000) 397. 
[16] G. Antou, G. Montavon, F. Hlawka, A. Cornet, C. Coddet, F. Machi, Surf. Coat. Technol. $172(2003) 279$.

[17] K.C. Chang, W.J. Wei, C. Chen, Surf. Coat. Technol. 102 (1998) 197.

[18] S. Ahmaniemi., P. Vuoristo, T. Mäntylä, Mater. Sci. Eng. A366 (2004) 175.

[19] S. Ahmaniemi, M. Vippola, P. Vuoristo, T. Mäntylä, F. Cernuschi, L. Lutterotti, J. Europ. Ceram. Soc. 24 (2004) 2247.

[20] J. Lawrence, L. Li, Surf. Coat. Technol. 162 (2002) 93.

[21] J.F. Li, L. Li, F.H. Stott, Int. J. Heat Mass Transfer 47 (2004) 1159.

[22] S.O. Chwa, A. Ohmori, Surf. Coat. Technol. 153 (2002) 304.

[23] Z. Zhou, N.Eguchi, H. Shirasawa, and A. Ohmori, J. Therm. Spray Technol. 8(3) (1999) 405.

[24] L. Pawlowski, J. Therm. Spray Technol. 8(2) (1999) 279.

[25] A.H. Wang, W.Y. Wang, C.S. Xie, W.L. Song, D.W. Zeng, Appl. Surf. Sci. 221 (2004) 293.

[26] L. Bradley, L. Li, F.H. Stott, Mater. Sci. Eng. A278 (2000) 204.

[27] L. Bradley, L. Li, F.H. Stott, Appl. Surf. Sci.138-139 (1999) 233.

[28] P. Scardi, M. Leoni, L. Bertamini, Thin Solid Films 278 (1996) 96.

[29] R.A. Miller, R.G. Garlick, J.L. Smialek, Ceram. Bull. 62 (12) (1983) 1355.

[30] A.N. Khan, J. Lu, H. Liao, Mater. Sci. Eng., A Struct. Mater.: Prop. Microstruct. Process. 359 (2003) 129.

[31] S. Ahmaniemi, P. Vuoristo, T. Mäntylä, , Surf. Coat. Technol. 151-152 (2002) 412. 
[32] G.A. Kolta, I.F. Hewaidy, N.S. Felix, Thermochim. Acta 4 (1972) 151.

[33] A.S. Khanna, S.K. Jha, Trans. Indian Inst. Met. 51 (5) (1988) 279.

[34] N. Wu, Z. Chen, S.X. Mao, J. Am. Ceram. Soc., 88 [3] (2005) 675.

[35] M.F. Trubelja, D.M. Nissley, N.S. Bornstein, J.T.D. Marcin, Pratt \& Whitney Thermal Barrier Coating Development, Advanced Turbine Systems Annual Program Review, Conference Proceedings, FETC Publications (1997). 


\section{Tables}

Table 1. Spraying parameters and coating characteristics

\begin{tabular}{ccccccc} 
& & & & & Spraying & Coating \\
& Material & Deposition & Power & Plasma gas & distance & thickness \\
& & technique & $(\mathrm{kW})$ & $(\mathrm{slpm})$ & & $(\mathrm{mm})$ \\
\hline Bond Coat & $\mathrm{NiCoCrAlY}$ & VPS & 50 & $50 / 9\left(\mathrm{Ar} / \mathrm{H}_{2}\right)$ & 275 & 150 \\
Top Coat & $\mathrm{ZrO}_{2}-8 \mathrm{wt} \% \mathrm{Y}_{2} \mathrm{O}_{3}$ & APS & 20.2 & $20 / 13(\mathrm{Ar} / \mathrm{He})$ & 90 & 350 \\
\hline
\end{tabular}


Table 2. Laser operating parameters

\begin{tabular}{lcc}
\cline { 2 - 3 } & $\mathrm{CO}_{2}$ laser & Nd:YAG laser \\
\hline Wavelength $(\mu \mathrm{m})$ & 10.6 & 1.064 \\
Average working power $(\mathrm{W})$ & 550 & 65 \\
Beam spot size $(\mathrm{mm})$ & 1.25 & 0.3 \\
Pulse frequency $(\mathrm{kHz})$ & 100 & 30 \\
Scanning speed $(\mathrm{mm} / \mathrm{min})$ & 12000 & 1200 \\
Track shift $(\mathrm{mm})$ & 0.9 & 0.1 \\
\hline
\end{tabular}


Table 3. Specimen abbreviations

\begin{tabular}{cccc}
\hline Corrosive agent & \multicolumn{2}{c}{ Specimen } \\
$\left(\mathrm{mg} / \mathrm{cm}^{2}\right)$ & Plasma-sprayed & Treated with $\mathrm{CO}_{2}$ laser & Treated with YAG laser \\
\cline { 2 - 4 } & & $\mathrm{CO}_{2}-\mathrm{V}_{2} \mathrm{O}_{5}$ & $\mathrm{YAG}_{2} \mathrm{~V}_{2} \mathrm{O}_{5}$ \\
$\mathrm{~V}_{2} \mathrm{O}_{5}-15$ & Sprayed- $\mathrm{Na}_{2} \mathrm{SO}_{4}$ & $\mathrm{CO}_{2}-\mathrm{Na}_{2} \mathrm{SO}_{4}$ & $\mathrm{YAG}_{4}-25$ \\
$\mathrm{Na}_{2} \mathrm{SO}_{2} \mathrm{SO}_{4}$
\end{tabular}




\section{Figure captions}

Fig. 1. Secondary-electron (SE) micrographs illustrating the surface morphology of the coatings prior to the hot corrosion test; (a) plasma-sprayed condition, (b) laser-glazed with $\mathrm{CO}_{2}$ laser and (c) laser-glazed with Nd:YAG laser.

Fig. 2. SE micrographs illustrating the surface view of coatings after the hot corrosion test: (a) Sprayed-Na2 $\mathrm{SO}_{4}$; (b) $\mathrm{CO}_{2}-\mathrm{Na}_{2} \mathrm{SO}_{4}$; (c) YAG-Na2 $\mathrm{SO}_{4}$; (d) Sprayed- $\mathrm{V}_{2} \mathrm{O}_{5}$; (e) $\mathrm{CO}_{2}-\mathrm{V}_{2} \mathrm{O}_{5}$; (f) YAG- $\mathrm{V}_{2} \mathrm{O}_{5}$; (g) Sprayed-MIX; (h) $\mathrm{CO}_{2}$-MIX; (i) YAG-MIX.

Fig. 3. EDS spectra acquired from the surface of coating Sprayed-MIX; (a) zirconia matrix, indicated as 2 in Fig $2 \mathrm{~g}$, (b) crystal on the surface, indicated as 1 in Fig $2 \mathrm{~g}$.

Fig. 4. XRD spectra of coatings before and after the hot corrosion testing; (a) plasma-sprayed condition, (b) laser-glazed with $\mathrm{CO}_{2}$ laser and (c) laser-glazed with Nd:YAG laser. (1) Before the corrosion testing; (2) tested with $\mathrm{Na}_{2} \mathrm{SO}_{4}$; (3) tested with $\mathrm{V}_{2} \mathrm{O}_{5}$ and (4) tested with $\mathrm{V}_{2} \mathrm{O}_{5}+\mathrm{Na}_{2} \mathrm{SO}_{4}$.

Fig. 5. Destabilization of zirconia coatings after the corrosion testing at $1000^{\circ} \mathrm{C}$ during 100 hours. Evaluation of the three sets of specimens: glazed with $\mathrm{CO}_{2}$ laser, glazed with $\mathrm{Nd}$ :YAG laser and as-sprayed condition; tested with $\mathrm{Na}_{2} \mathrm{SO}_{4}, \mathrm{~V}_{2} \mathrm{O}_{5}$ and $\mathrm{V}_{2} \mathrm{O}_{5}+\mathrm{Na}_{2} \mathrm{SO}_{4}$.

Fig. 6. View of the surface of Sprayed-MIX coating in a region where a large portion of material has spalled. 
Fig. 7. Cross-sectional backscattered-electron micrographs of coatings (a) $\mathrm{CO}_{2}-\mathrm{MIX}$ and (c) Sprayed-MIX; (b) and (d) are closer views from a region near the top coat/bond coat interface of the images on the left.

Fig. 8. Cross-sectional SE view of a fracture plane of coating $\mathrm{CO}_{2}-\mathrm{MIX}$ after the corrosion testing. The laser glazed coating presented regions where the top glazed layer was detached from the plasma-sprayed microstructure. 


\section{List of figures}
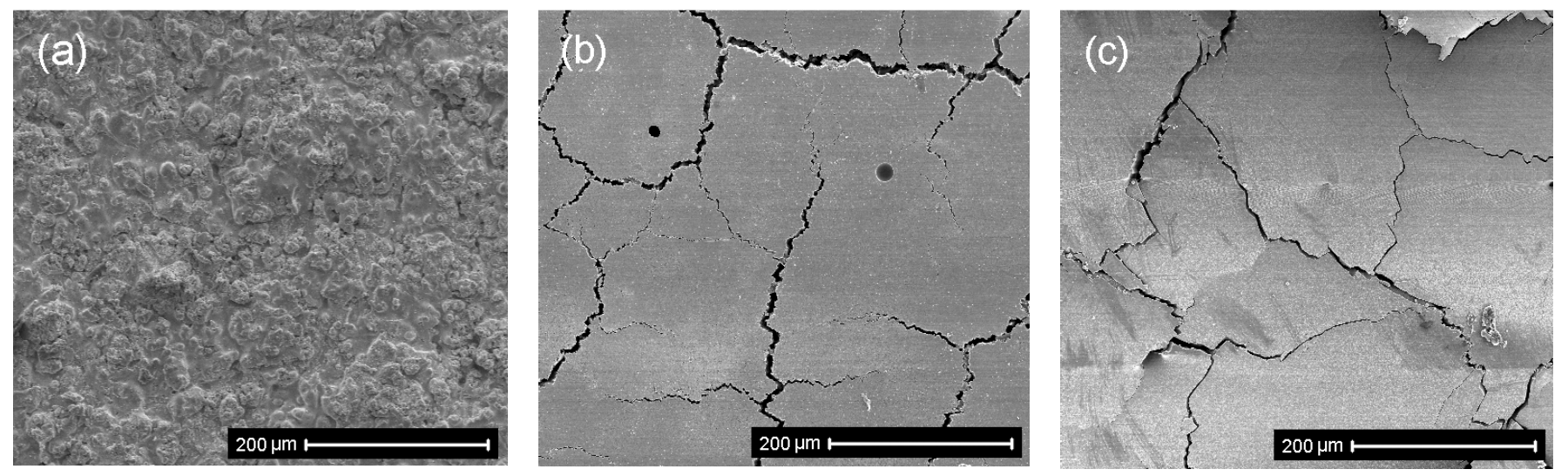

Fig. 1 

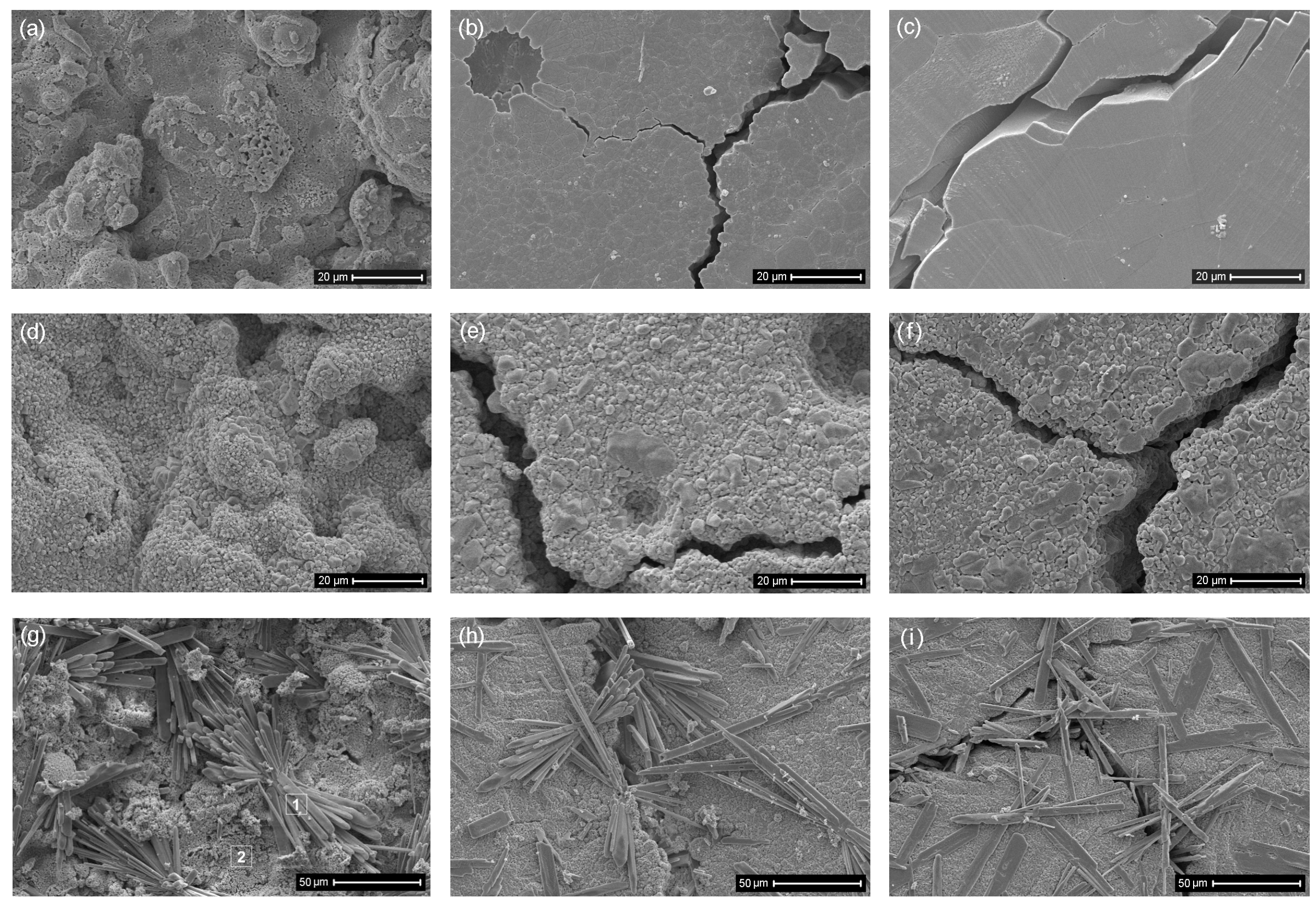

Fig. 2

-26 - 
X-RAY: $00-20$ keU
Live: 1005 Preset: 100s Remaining: 05
Real: 1155 13\% Dead

(a)
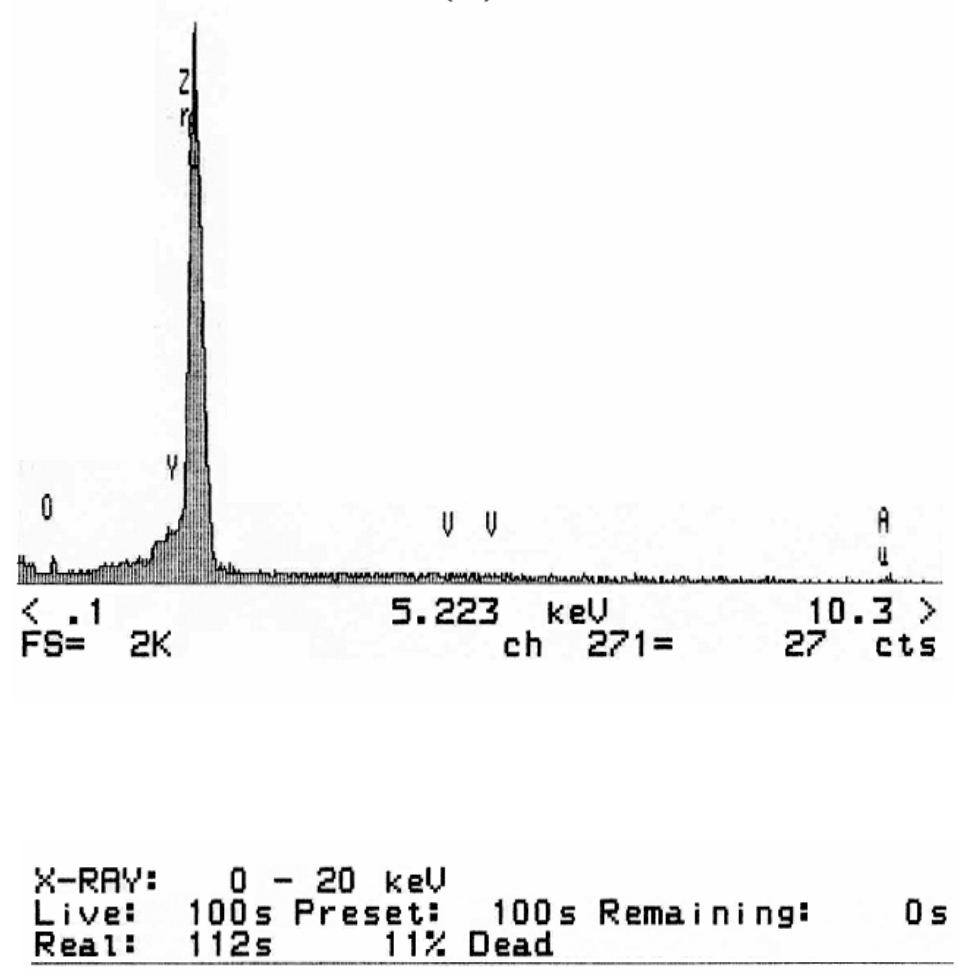

(b)

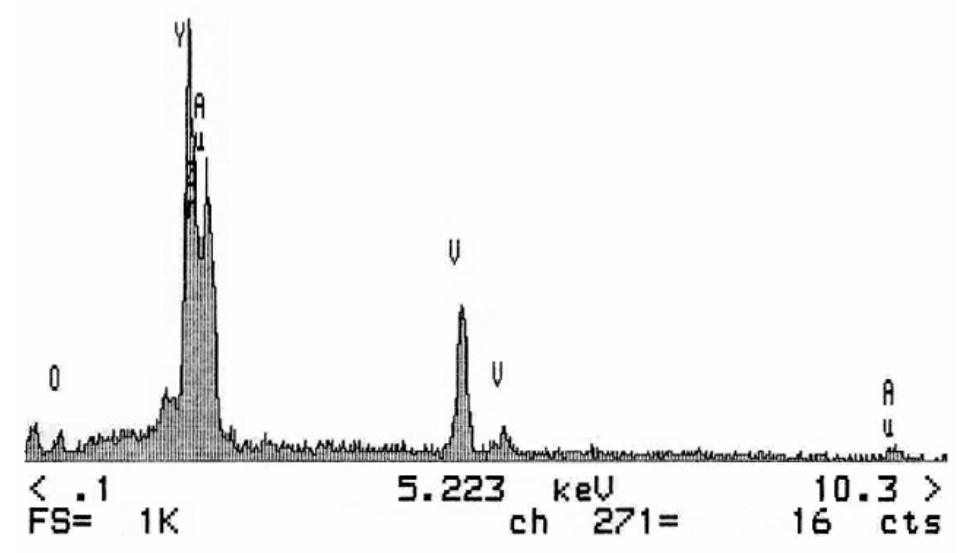

Fig. 3

-27 - 

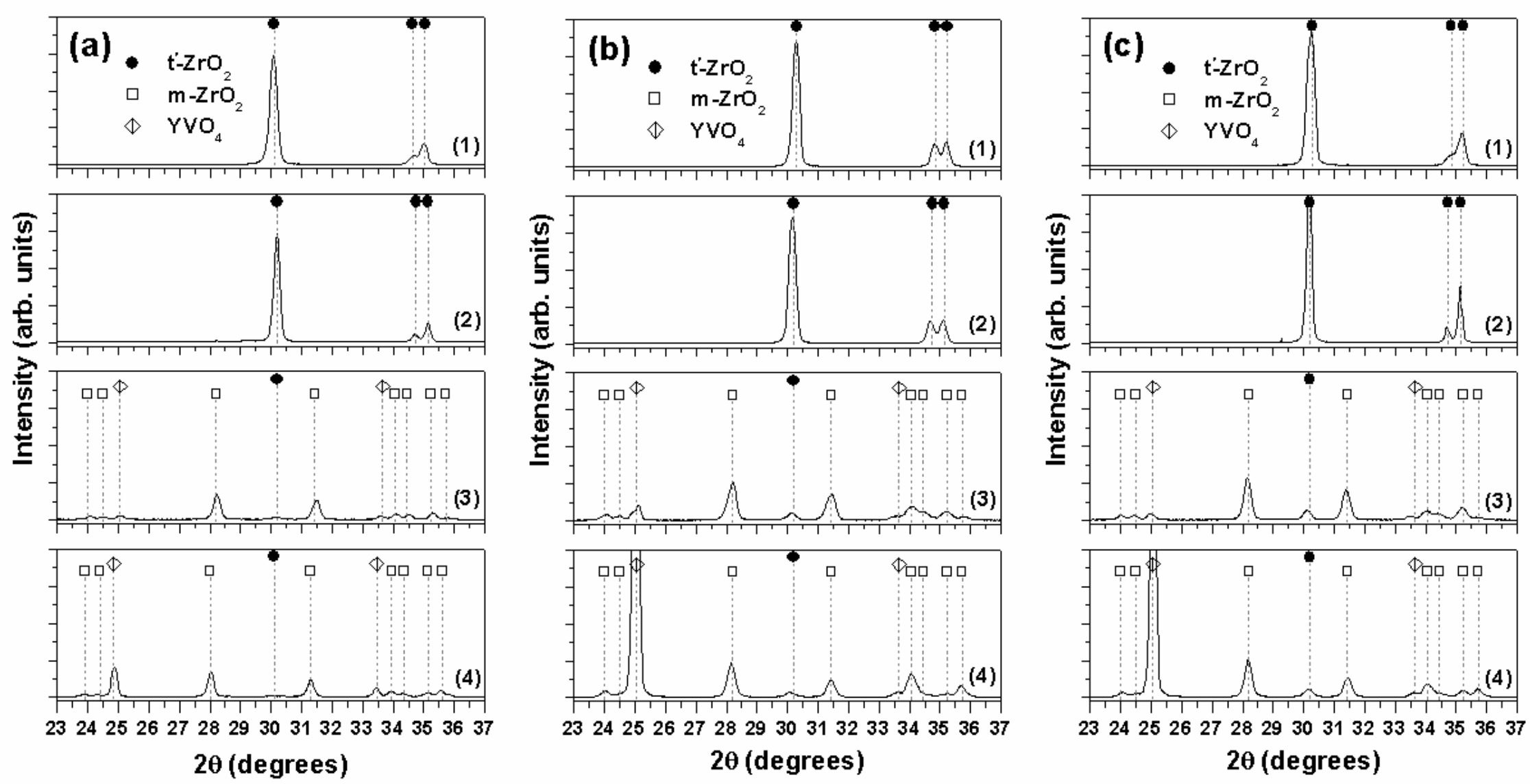

Fig. 4 


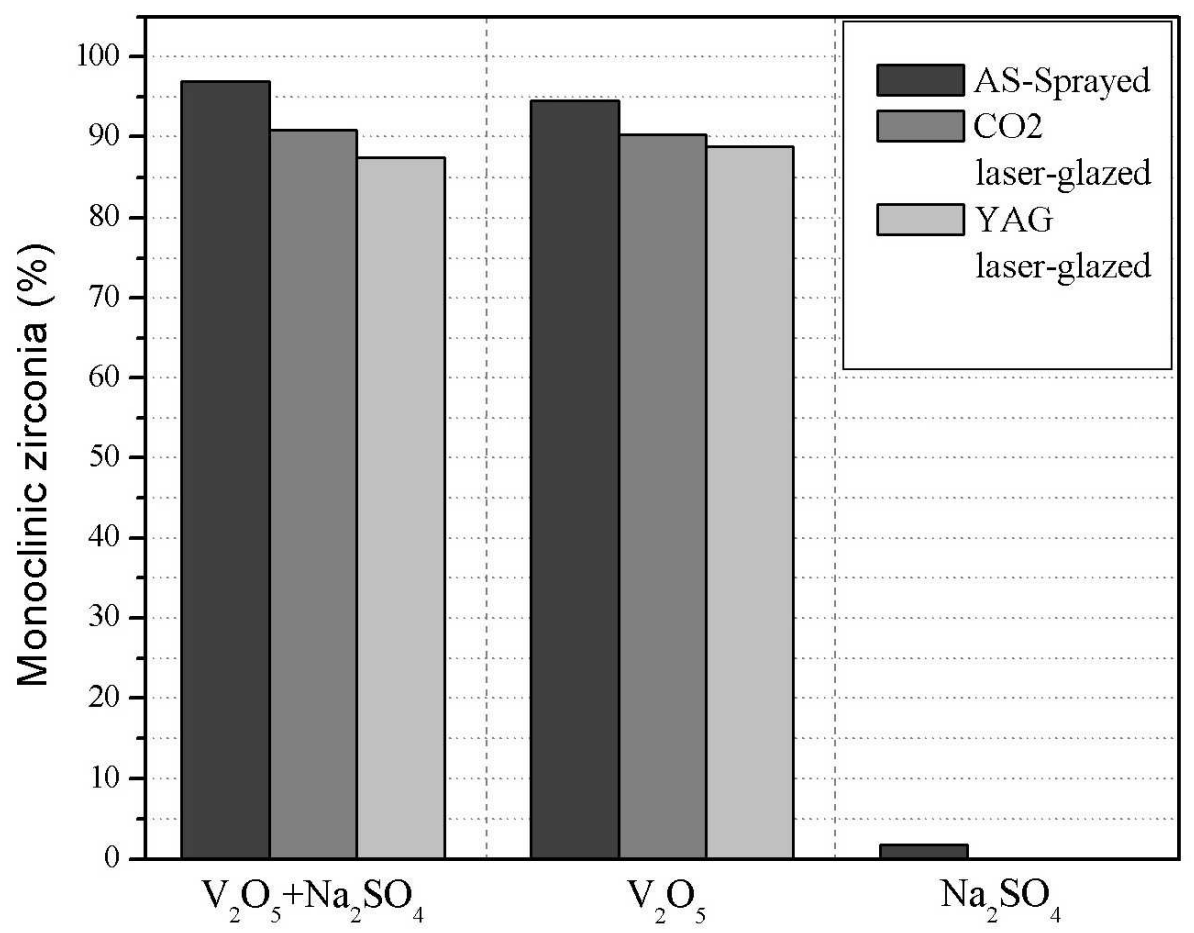

Fig. 5

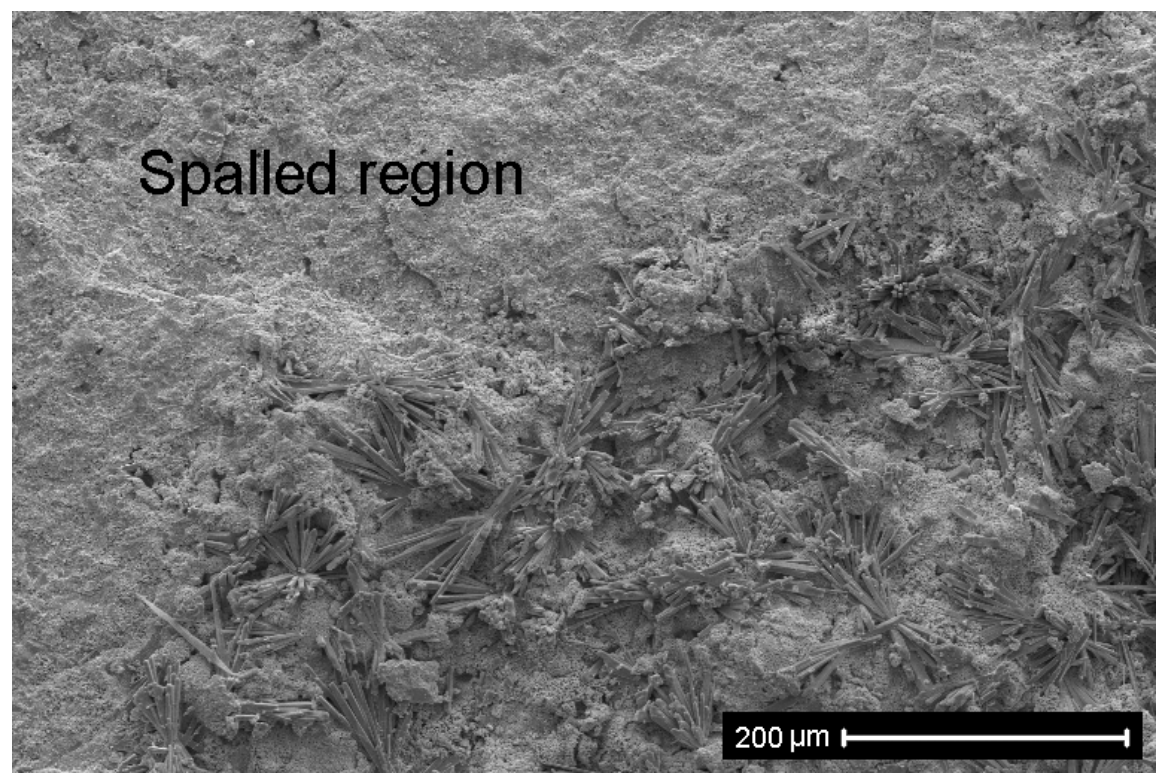

Fig. 6 

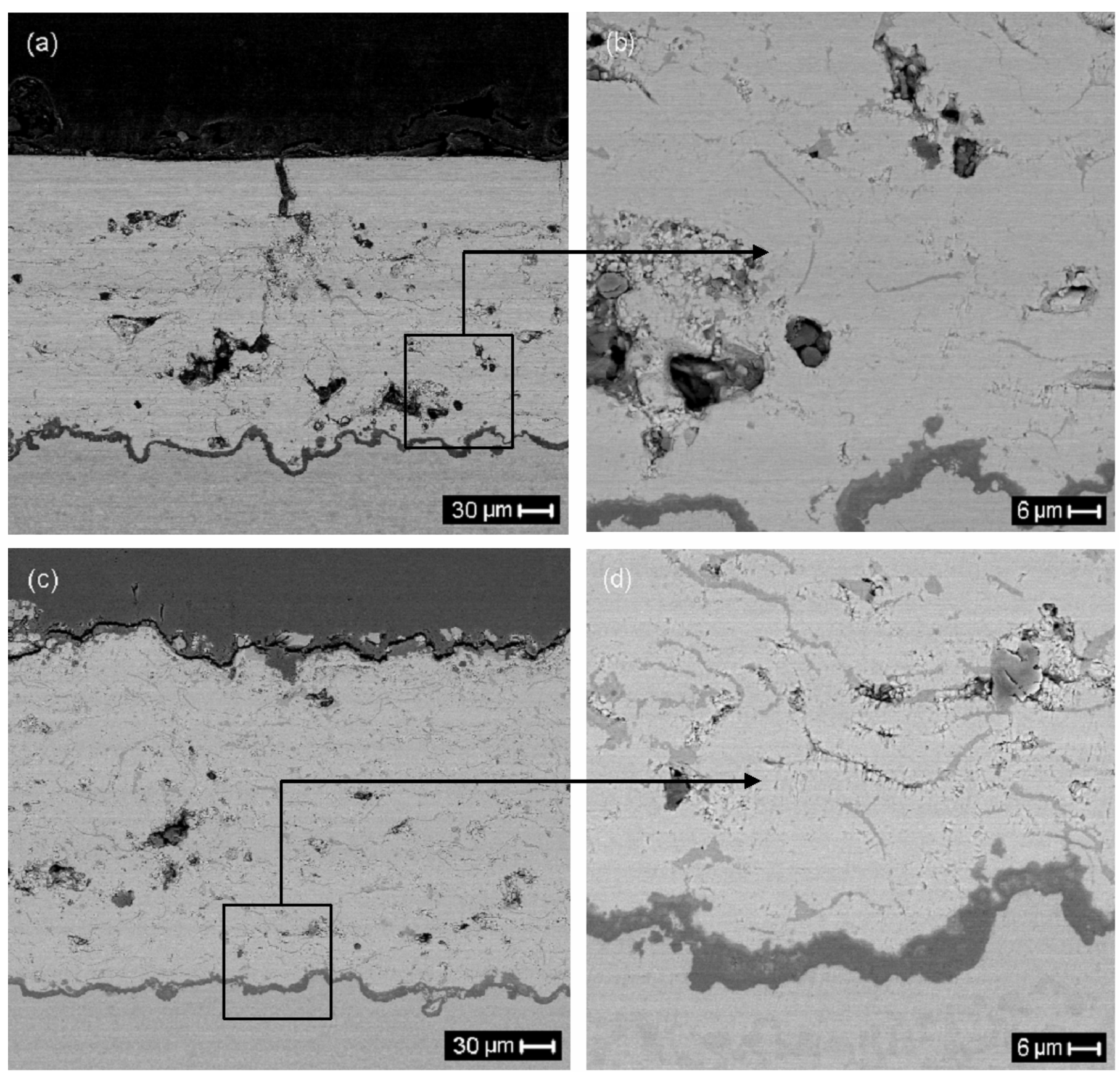

Fig. 7 


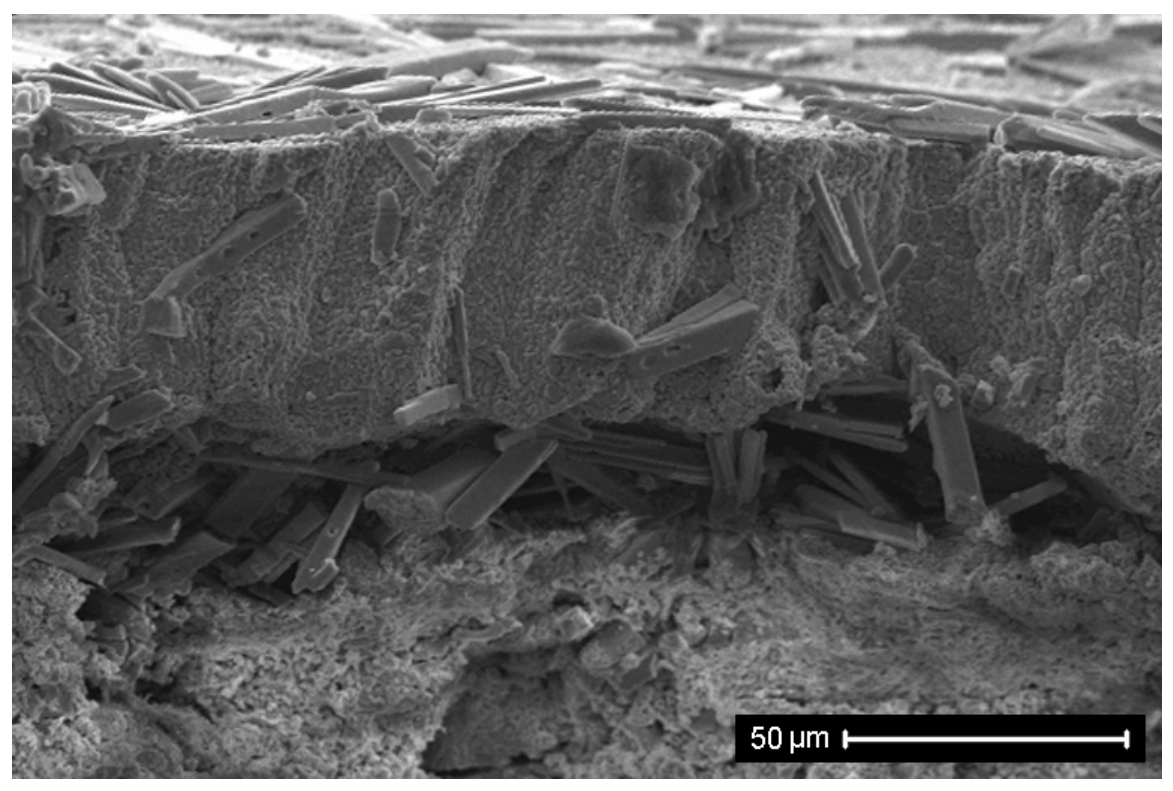

Fig. 8 